
The publisher gratefully acknowledges the generous contribution to this book provided by the Ahmanson Foundation Humanities Endowment Fund of the University of California Press Foundation. 
Wagner Beyond Good and Evil 


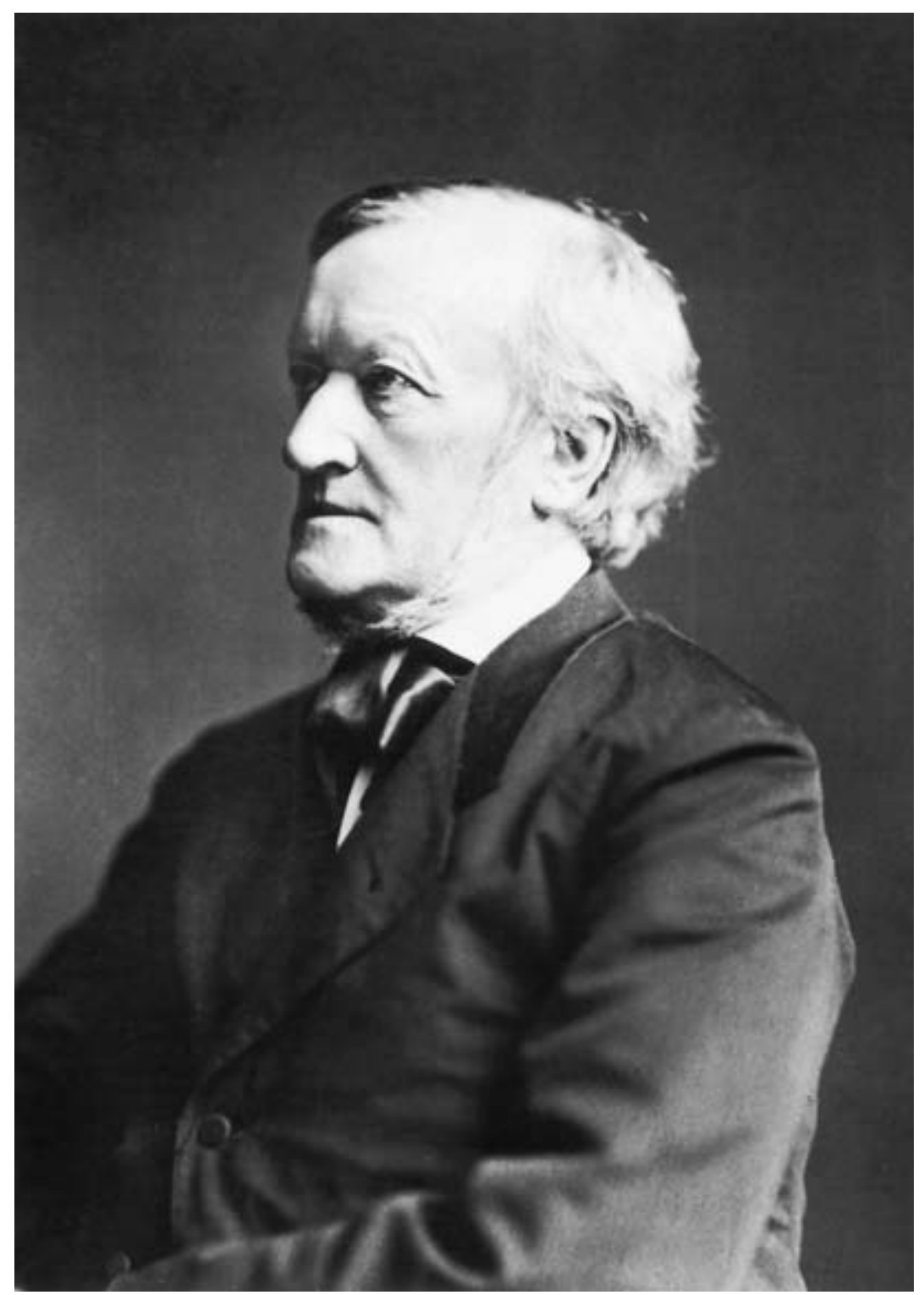

Photograph of Wagner taken on I May 1882 in the studio of Joseph Albert, Munich. Courtesy of the Theatermuseum, Munich. 


\section{Wagner Beyond Good and Evil}

JOHN DEATHRIDGE

甲

University of California Press

BERKELEY LOS ANGELES LONDON 
University of California Press, one of the most distinguished university presses in the United States, enriches lives around the world by advancing scholarship in the humanities, social sciences, and natural sciences. Its activities are supported by the UC Press Foundation and by philanthropic contributions from individuals and institutions. For more information, visit www.ucpress.edu.

University of California Press

Berkeley and Los Angeles, California

University of California Press, Ltd.

London, England

(C) 2008 by The Regents of the University of California

Library of Congress Cataloging-in-Publication Data

Deathridge, John.

Wagner beyond good and evil / John Deathridge.

p. $\mathrm{cm}$.

Includes bibliographical references and index.

ISBN: 978-0-520-25453-4 (cloth : alk. paper)

1. Wagner, Richard 1813-1883-Criticism and interpretation.

2. Opera-19th century. I. Title.

ML 410.W13D35 2008

782.1092-dc22 2008004589

Manufactured in the United States of America

$\begin{array}{llllllllll}17 & 16 & 15 & 14 & 13 & 12 & 11 & 10 & 09 & 08\end{array}$

$\begin{array}{llllllllll}10 & 9 & 8 & 7 & 6 & 5 & 4 & 3 & 2 & 1\end{array}$

This book is printed on New Leaf EcoBook 50, a 100\% recycled fiber of which $50 \%$ is de-inked post-consumer waste, processed chlorine-free. EcoBook 50 is acid-free and meets the minimum requirements of ANSI/ASTM D 5634-O1 (Permanence of Paper). 
To my mother and in memory of my father 
